\title{
PERJUANGAN PENDIDIKAN KARTINI VS RAHMAH EL YUNUSIYYAH BAGI PEREMPUAN INDONESIA: SEBUAH PENDEKATAN HISTORIS DAN KULTURAL
}

\author{
Najmi \& Ofianto \\ Jurusan Sejarah, Universitas Negeri Padang
}

\begin{abstract}
Abstrak: Tokoh-tokoh perempuan dalam sejarah bangsa Indonesia adalah hal yang masih menarik untuk dituliskan. Berbagai pro-kontra munculnya tokohtokoh tersebut tidak menyurutkan para perempuan modern untuk menjadikan tokoh-tokoh tersebut menjadi sumber inspirasi mereka. Kartini misalnya, yang selalu menjadi tokoh utama perempuan dalam sejarah Indonesia dan dijadikan pahlawan bangsa. Berbagai pendapat mengenai Kartini memang tidak ada salahnya, namun hal tersebut harus diluruskan dengan berbagai pendekatan sejarah baik secara tekstual maupun kontekstual. Selain Kartini, tokoh perempuan yang nantinya akan dijadikan sebagai komparasi yaitu Rahmah El Yunusiyyah. Kartini yang berasal dari Jawa, hampir semua kalangan masyarakat mengenal beliau, berbeda dengan Rahmah El Yunusiyyah yang berasal dari Minangkabau (Sumatera Barat) mungkin tidak semua kalangan yang mengenal beliau serta kiprahnya dalam sejarah bangsa. Namun, dua tokoh ini bisa dikatakan memiliki tujuan yang sama dengan ideologi yang berbeda dan nuansa budaya pun jauh berbeda. Di sinilah keunikan dari dua tokoh ini yaitu memiliki cita-cita dan tujuan yang sama yaitu menaikkan derajat kaum perempuan melalui pendidikan namun dengan pandangan yang sangat berbeda.
\end{abstract}

Kata-kata kunci: perempuan Jawa, Minangkabau, pendidikan perempuan

\begin{abstract}
Women figures in the history of Indonesia is still attractive to be written. Various pros and cons of the emergence of these figures do not discourage the modern women to make these characters become their source of inspiration. Kartini, for example, which has always been a heroine in the history of Indonesia and as a hero. Some opinions on Kartini are not wrong, but it should be straightened with a variety of historical approaches both textual and contextual analyses. Besides Kartini, a female character which will be used as a comparison that is Rahmah El Yunusiyyah. Kartini from Java, almost all people know him, in contrast to Rahmah El Yunusiyyah originating from the Minangkabau (West Sumatra) may not all people who know him and his work in the nation's history. However, these two figures can be said to have the same goal with different ideologies and cultural nuances too much different. This is where the uniqueness of these two figures that have ideals and the common goal of raising the level of women through education, but with a very different view.
\end{abstract}

Keywords: Javanese woman, Minangkabau, education for woman

Dua tokoh perempuan yang sangat berperan dalam memperjuangkan hak perempuan Indonesia untuk mendapatkan pendidikan namun berbeda generasi dan kultur bisa disematkan pada Kartini dan Rahma El Yunusiyyah. Dua tokoh perempuan yang berbeda karakter dan kultur ini memiliki cita-cita yang sama dan mulia yaitu ingin membuat perempuan Indonesia lebih maju dan bermartabat yaitu dengan mengecap pendidikan. Perbedaannya, Kartini dengan harapannya yang sangat besar ingin mendapatkan pendidikan barat di Eropa harus kandas oleh politik kolonial ketika itu yang menganggap Kartini "agak revolusioner", yang juga membahayakan kedudukan kaum kolonialis di Hindia Belanda (Srinthi, 2006: 47). Kartini juga 
mendapat tekanan dari Ayahnya dari kaum priyayi Jawa yang sangat feodalis. Dalam arti lain, Kartini diapit oleh dua hal yang sangat mengganggu pikirannya yaitu kolonialisme dan feodalisme. Berbeda dengan Kartini, Rahmah El Yunusiyyah dalam proses perjuangannya tidak mau dibantu sama sekali oleh pemerintah kolonial. Ini terlihat ketika pemerintah kolonial mau membantu Rahmah dalam hal subsidi untuk sekolah yang didirikannya, namun selalu ditolaknya (Saydam, 2009: 208).

Bercerita tentang Kartini tidak akan ada habisnya. Pergolakan batin Kartini yang menyentuh hati membuat beliau patut dijadikan pioneer atau pahlawan di bidang pendidikan. Walaupun beberapa ahli serta masyarakat awam masih meragukan kepahlawanan Kartini, tapi itu tidak menjadi masalah. Ada yang menganggap bahwa suratsurat Kartini tidak membuktikan apa-apa dan sekolah yang beliau dirikan pun dikatakan kurang berhasil karena sekolah tersebut hanya untuk kaum priyayi jawa saja. Pendidikan yang diajarkan Kartini di sekolah tersebut juga hanya mengajarkan bagaimana perempuan seharusnya di dalam ruang domestik. Selain itu, baru sebulan menjadi guru di sekolah perempuan yang beliau dirikan, Kartini harus rela dijodohkan oleh ayahnya dengan bupati Rembang (Rosyadi, 2010: 37). Kuatnya patriarkis Jawa ini menjadi tantangan terbesar bagi Kartini, namun beliau tidak gentar memperjuangkan haknya dan kaum perempuan Jawa lainnya dalam meraih pendidikan.

\section{PENDIDIKAN VERSI KARTINI}

Kartini adalah perempuan yang berprinsip. Prinsip-prinsip yang dianutnya dengan jelas tertuang dalam surat-suratnya tersebut. Sayangnya prinsip-prinsip beliau masih saja kalah oleh keadaan dan kenyataan. Salah satu prinsip tersebut adalah, "poligami". Beliau sangat tidak menyukai praktek poligami, karena dimulai dari ibunda Kartini yang harus rela dipoligami oleh sang ayah. Selain itu, ibunda Kartini yang tidak berasal dari kalangan bangsawan yang awalnya adalah istri pertama, harus rela di kemudian hari menjadi istri kedua dan juga harus meninggalkan kediaman sang suami karena Ngasirah (ibunda Kartini) telah berubah status menjadi selir.Kartini sendiri juga harus rela menjadi istri ketiga dari suaminya. Hal ini tentu menjadi pukulan bagi Kartini. Di satu sisi, jiwanya sangat menolak namun di sisi lain, ayahnya mulai sakit-sakitan.

Ditelusuri lebih jauh, Kartini adalah perempuan modern yang terkurung oleh keadaan. Pola pikirnya tidak seperti perempuan bumiputra pada umumnya atau bisa dibilang sudah genius untuk zaman itu. Beliau bisa dikatakan sebagai perempuan modern yang hidup di masa dan keadaan yang tidak tepat. terlepas dari asumsi tersebut, surat-surat Kartini tidak hanya menuliskan penderitaan serta kepedihan hidup yang beliau rasakan. Kartini juga menuliskan tentang keadaan rakyat yang sangat menderita akibat dari penjajahan yang dilakukan oleh pemerintah kolonial (Wierenga, 1999: 101).

Kartini adalah seorang pendidik dan seorang inspirator. Walaupun cuma beberapa saat menjadi seorang guru, jiwa pendidiknya tidak lepas begitu saja. Kartini mengajarkan pada saudara-saudara perempuannya bagaimana menulis yang baik dan belajar bahasa Belanda. Ini terlihat dari surat-surat Kartini yang juga terselip beberapa surat dari adik-adiknya Roekmini, Kardinah, Kartinah, dan Soemantri. Beliau mengajarkan bahwa menulis itu sangat bermanfaat. Menulis itu dihasilkan dari membaca. Kartini sangat senang sekali membaca buku dan koran, dari buku-buku yang dibacanya Kartini menjadi makin bersemangat untuk menulis. 
Tidak banyak perempuan dari kalangan priyayi Jawa yang hebat menulis seperti Kartini. Walaupun dikekang oleh adat Jawa yang sangat kental, Kartini tidak kehilangan akal untuk mencari ilmu. Ini terlihat akan hobinya membaca dan menulis. Tulisan Kartini pun tidak hanya sebatas sebuah surat untuk para sahabatnya, tetapi gaya penulisan Kartini yang juga sudah sistematis. Selain itu, tulisan kartini dalam surat-suratnya dituliskan dalam bentuk bahasa Belanda. Hal inilah yang membuat Kartini sangat pantas dibilang "genius", walaupun pada akhirnya harus menyerah pada tuntutan adat dan pernikahan yang harus beliau jalani.

Ide Kartini tentang pendidikan memiliki konsep yang sangat luas. Kartini menjadikan pendidikan sebagai sarana perjuangan. Artinya perjuangan untuk mendapatkan kesetaraan dan perjuangan untuk memperoleh kemerdekaan. Pendidikan sebagai sarana mendapatkan kesetaraan, terlihat dari penggalan surat Kartini kepada Stella Zeehandelaar tertanggal 23 Agustus 1900, yang isinya (Kartini, 1963: 72-73):

"Ingin hatiku hendak beranak, laki-laki dan perempuan, akan ku didik, ku bentuk jadi manusia sepadan dengan kehendak hatiku. Pertama-tama akan kubuangkan adat kebiasaan yang buruk, yang melebih-lebihkan anak laki-laki dari pada anak perempuan. Tidak usah kita herankan lagi apa sebabnya nafsu laki-laki memikirkan dirinya sendiri saja, bila kita ingat, bahwa laki-laki sejak semasa kecilnya, sudah dipelebih-lebihkan dari pada anak perempuan. Dan semasa kanak-kanak, lakilaki itu sudah diajar merendahkan derajat anak perempuan itu. Bukankah acap kali ku dengar seorang ibu berkata kepada anaknya laki-laki, bila dia jatuh, lalu menangis;..tjis anak laki-laki menangis, tiada malu, seperti anak perempuan!" Anakku, laki-laki maupun perempuan akan aku ajar, supaya menghargai dan pandangmemandang sama rata, makhluk yang sama, dan didikannya akan ku samakan benar; yakni tentu saja masing-masing menurut kodrat kecakapannya."

Dari penggalan surat Kartini tersebut, jelas Kartini memiliki pemikiran yang sangat terbuka dan ingin menerapkan kesetaraan antara anak laki-laki dan perempuan. Kesetaraan itu ingin beliau terapkan dan lakukan, tidak hanya dalam mendapatkan pendidikan tetapi juga mengubah tradisi yang mendiskreditkan perempuan. Zaman ketika itu, bisa dikatakan tidak banyak perempuan yang bersikap dan berpikir seperti Kartini.

Pikiran Kartini juga tidak terlepas dari pengaruh pola pendidikan barat. bDi mana para sahabat Kartini di Eropah, lebih mendapat tempat bagi perempuan dalam hal pendidikan dan ruang publik lainnya. Kartini juga ingin menerapkan keterbukaan orang barat tentang konsep kebebasan di mana laki-laki juga memiliki hak yang sama dengan perempuan.

Pendidikan sebagai sarana perjuangan, juga salah satu konsep Kartini yang belum kesampaian. Kartini ingin sekali rakyat, tidak hanya kaum priyayi, juga mendapatkan pendidikan sebagai sarana untuk berjuang melawan penjajahan. Ini terlihat dari sambungan penggalan surat beliau kepada Stella Zeehandelaar tertanggal 23 Agustus 1900 (Kartini, 1963: 72-73), yang isinya:

"Kerap kali aku bertemu dengan orang kulit putih, yang sekali-kali bukan bodoh, malahan pikirannya cerdas, tetapi congkaknya bukan main, tiada tahan. Hal ini menyakitkan hatiku bukan, dan terlalu 
banyak kali menyampaikan perasaannya kepada kami, bahwa kami orang Jawa bukan manusia. Bagaimana mungkin orang Belanda hendak kami - orang Jawakasih sayangi, apabila kami diperlakukannya secara demikian. Cinta membangkitkan balasan cinta, tetapi penghinaan selamalamanya tiada akan menghidupkan rasa cinta."

Lewat tulisannya tersebut, beliau sangat mengkritik orang Belanda yang menghina rakyat (khususnya Jawa). Rakyat diperlakukan layaknya budak dan dihina secara ras atau etnisitas. Belanda menganggap bahwa bumiputera hanya suruhan dan bisa diperlakukan semena-mena. Hal ini juga tidak terlepas dari kebijakan Belanda yang membagi strata sosial masyarakat jajahannya, di mana bangsa Barat adalah memiliki derajat atau strata sosial tertinggi, di bawahnya ada bangsa Cina/Timur Asing lainnya, baru yang paling terbawah adalah pribumi. Ini diberlakukan oleh Belanda dalam sistem pemerintahannya di Hindia Belanda (Indonesia). Melihat penghinaan tersebut, Kartini merasa sangat terhina batinnya, jadi merasa bahwa kemerdekaan adalah haknya semua manusia, bukan cuma kulit putih saja.

Selain terkurung oleh penjajah, Kartini juga terbelenggu oleh adatnya sendiri. Hal ini sebenarnya juga persoalan bagi kaum priyayi Jawa ketika itu. Bangsa penjajah yang mengatur semua kebijakan, terpaksa harus diikuti oleh para kaum bangsawan, karena berada di bawah ancaman. Sehingga perempuan menjadi korban yang paling tidak mendapatkan hak apalagi kemerdekaannya sebagai perempuan. Ini permasalahan yang cukup rumit ketika itu. Kartini pun melihat, bahwa berada dalam lingkungan seperti itu adalah dilema yang susah untuk diperjuangkan. Ujungujungnya, beliau hanya bisa meluapkan perasaannya lewat tulisan-tulisannya.

Kartini adalah perempuan cerdas, beliau yang hidup dalam nuansa penjajahan dan kekangan adat masih berpikir jauh ke depan. Konsep kesetaraan sudah ada dalam benak beliau, yang tidak semua semua perempuan bisa seperti beliau ketika itu. Inilah konsep pikiran beliau yang sudah diterapkan oleh perempuan di zaman modern sekarang.

\section{PENDIDIKAN VERSI RAHMAH EL YUNUSIYYAH}

Meninggalkan Kartini, tokoh perempuan di masa yang hampir bersamaan dan di tempat serta budaya yang berbeda yaitu dari Minangkabau bernama Rahmah El Yunusiyyah. Sedikit menyinggung tentang konsep kesukuan Minangkabau sebagai pengantar karakter perempuan Minangkabau itu sendiri. Rahmah adalah perempuan Minangkabau yang kental dengan agama Islam. Beliau tumbuh di tengah-tengah pendidikan Islam yang sangat kental, sehingga bentuk pendidikan yang diterapkannya pun bernuansa Islami namun pendidikan ilmu pengetahuan umum pun beliau pelajari dan ajarkan di sekolah yang beliau dirikan.

Berbeda dengan Kartini hanya bisa menyampaikan idenya melalui surat-surat pribadi kepada para sahabatnya di negeri Belanda, Rahmah sudah bisa menerapkan ide-idenya secara lebih nyata. Rahmah berhasil mendirikan sekolah khusus perempuan (keputrian) yang diberi nama Diniyyah Putri. Kartini terkekang oleh adat Jawa, tidak begitu dengan Rahmah. Minangkabau yang menganut sistem kekerabatan Minangkabau, memposisikan perempuan itu sangat istimewa baik dari segi keturunan maupun posisi perempuan itu sendiri. Walaupun dalam prakteknya, perempuan Minangkabau tidak memiliki posisi utama dalam pengambilan keputusan 
misalnya dalam musyawarah adat, lakilakilah yang berhak mengambil keputusan, laki-laki di sini yaitu para penghulu suku maupun kaum (pemimpin adat).

Dalam sistem matrilineal, idealnya perempuanlah yang memiliki kekuasaan yang besar, namun kekuasaan itu tidak berlaku dalam kepemilikan hak suara di keluarga/suku/kaum. Kenyataannya perempuan masih belum leluasa seperti lakilaki, masih ada sekat geneologis perempuan, di mana perempuan dianggap lemah dan posisinya masih berada di bawah laki-laki. Perempuan hanya berhak memberikan ide maupun saran dalam pengambilan keputusan.

Penempatan perempuan sebagai pusat pada adat matrilineal didukung oleh ajaran Islam. Kuatnya nilai kekerabatan pada masyarakat Minangkabau dapat dan akan menjadi budaya (adat) Minangkabau lantaran adanya rasa kebersamaan dan malu, lebih-lebih dengan tuntutan ajaran Islam (Nuryanti, 2011: 23, Bandaro, 2004: 246).Apa yang tampak dalam adat, juga tercantum dalam Al-Quran dan hadits yang disampaikan oleh Nabi Muhammad SAW.

Di dalam sistem kekerabatan matrilineal di Minangkabau ini, perempuan menjadi aktor yang paling berpengaruh. Watak keminangan yang tumbuh dalam jiwa perempuan Minangkabau secara tidak langsung tertanam dari bentuk nyata kekerabatan tersebut. Mereka tumbuh dan berkembang dengan mendudukkan diri dalam dua peranan, yakni sebagai bundo kanduang dan sebagai perempuan biasa yang sudah menikah. Bundo kanduang dianggap sebagai perempuan yang utama dan mempunyai kekuasaan yang lebih tinggi dari seorang penghulu. Ini dikarenakan bundo kanduang dipandang setingkat dengan ibu.

Sedikit persamaan dengan adat Jawa awal abad 20-an, di Minangkabau juga diwarnai dengan namanya poligami. Pada masa ini, bukan hal aneh bagi perempuan Minangkabau, jika suaminya menikah lagi atau mempunyai istri lebih dari satu. Ini disebabkan karena dua faktor, pertama karena laki-laki dalam adat setelah menikah hanya berstatus sumando, di mana tidak boleh menetap lama-lama di rumah sang istri. Ada beberapa pendapat menyatakan, bahwa laki-laki yang berstatus sumando hanya untuk tujuan biologis/keturunan atau menghasilkan keturunan. Jadi tidak bisa menetap lama-lama di rumah sang istri. Faktor kedua yaitu karena kebutuhan ekonomi. Faktor kedua ini, biasanya untuk kedudukan laki-laki yang berstatus penghulu atau datuak. Hal ini untuk menaikkan prestise penghulu, di mana memiliki istri lebih dari satu menjadikan posisinya makin tinggi di dalam masyarakat.

Dihubungkan dengan Rahmah yang juga perempuan Minangkabau, memiliki budaya Minang yang berlandaskan Islam yang taat. Beliau juga dipanggil Bundo Kanduang barisan perjuangan, karena peranan aktifnya dalam mendukung barisan perjuangan seperti BKR, TKR (yang kemudian menjadi TNI). Sebagai seorang aktivis Islam beliau juga aktif dalam dunia politik. Melihat kepiawaian beliau dalam dunia pendidikan dan politik, perlu rasanya beliau dicatat dalam sejarah perempuan Indonesia yang memiliki peranan besar baik dalam pendidikan maupun dalam perjuangan membela kemerdekaan.

Dalam perjalanan karirnya sebagai seorang pendidik, Rahmah mendapatkan pengetahuan secara otodidak dari saudara laki-lakinya. Beliau anak bungsu yang memiliki karakter yang sangat pemalu namun keras hati. Beliau juag memiliki citacita yang hampir sama dengan Kartini yaitu memajukan kaum perempuan dari sisi pendidikan.

Core Vreede dan De Stuers menyatakan ketokohan Rahmah digambarkan 
menjadi dua sisi, pertama seperti Ki Hajar Dewantara karena mendirikan sebuah lembaga pendidikan atas inisiatif sendiri. Kedua seperti Kartini karena berjuang memperbaiki posisi perempuan melalui pendidikan(Syafieh.blogspot.co.id, 2013). Rahmah adalah sosok perempuan yang termasuk beruntung, hal ini bisa dilihat dari sisi asal-usul keturunannya yang merupakan anak dari seorang ulama besar di zamannya, yang bernama Syekh Muhammad Yunus (1846-1904 M). Ibu Rahmah juga berasal dari keturunan para ulama besar, di mana nenek moyang Ummi Rafi'ah (Ibunda Rahmah) empat tingkat di atasnya masih ada hubungan dengan mamak Haji Miskin, sang Pembaharu Gerakan Paderi. Dilihat dari silsilah tersebut, Rahmah memiliki asal-ususl keturunan yang patut diperhitungkan dalam sejarah penjajahan dan perjuangan melawan kolonialisme.

Pandangan Rahmah terhadap perempuan tidak terlepas dari ajaran yang dianutnya. Beliau menganggap peermpuan adalah pendidik pertama dan utama bagi anak-anak yang akan menjadi generasi penerus bangsa. Atas dasar itu, untuk meningkatkan kualitas dan memperbaiki kedudukan perempuan diperlukan pendidikan khusus kaum perempuan yang diajarkan oleh kaum perempuan sendiri. Dalam hal ini, perempuan perlu meningkatkan kemampuan di bidang intelektual, kepribadian maupun keterampilan.

Tujuan pendidikan perempuan menurut Rahmah adalah meningkatkan kedudukan kaum perempuan dalam masyarakat melalui pendidikan modern yang berlandaskan prinsip-prinsip Islam. Beliau percaya bahwa perbaikan posisi kaum perempuan dalam masyarakat tidak dapat diserahkan kepada pihak lain, hal ini harus dilakukan oleh kaum perempuan sendiri. Melalui pendidikan, perempuan harus bisa lebih maju sehingga pandangan yang mensubordinasikan peran perempuan lambat laun akan hilang dan akhirnya kaum perempuan pun akan menemukan kepribadiannya secara utuh dan mandiri dalam mengemban tugasnya sejalan dengan petunjuk agama.

Cita-citanya di dalam bidang pendidikan dapat terealisasi ketika Rahmah berhasil mendirikan sekolah khusus untuk anak perempuan. Perempuan Minangkabau pasa masa itu, tidak banyak yang memiliki pendidikan dan pengetahuan serta hanya terkurung oleh keadaan dan beberapa aturan adat yang mengikat seperti menikah pada usia yang sudah dianggap "patuik" (patut) dan perjodohan. Pendidikan bagi perempuan pada masa itu pun tidak terlalu dianggap penting, karena perempuan bertugas melayani suami dan membesarkan anak. Melihat kondisi tersebut, Rahmah sangat terdorong untuk menjadikan perempuan Minangkabau lebih maju dan cerdas dengan mendirikan sekolah khusus perempuan. Selain pengetahuan umum yang minim pada perempuan Minangkabau, pengetahuan mengenai agama Islam juga belum sepenuhnya dimengerti oleh perempuan Minang katika itu, karena perempuan banyak berada di rumah dan melakukan pekerjaan rumah.

Perjuangan Rahmah dalam memperluas pendidikan bagi kaum perempuan, tidak hanya di kota kelahirannya saja yaitu Padang Panjang. Beliau juga menyebarkan pengetahuan yang dimilikinya sampai ke Batavia yang sebelumnya beliau sudah keliling Sumatera hingga Malaka. Pada tahun 1935, Rahmah mendirikan tiga buah perguruan putri di Batavia (Jakarta) yaitu di Kwitang, Jatinegara, dan di Tanah Abang. Pada masa pendudukan Jepang, perguruan tersebut tidak dapat diteruskan. Menjelang berakhirnya penjajahan Belanda di Indonesia, Rahmah sempat pula mendirikan empat buah lembaga pendidikan putri baru lainnya sebagai pengganti lembaga pendidikan terdahulu. Pada tahun 1938 ia mendirikan 
Yunior Institut Putri, sebuah sekolah umum setingkat dengan sekolah rakyat pada masa penjajahan Belanda atau Vervolgschool, Islamitisch Hollandse School (IHS) setingkat dengan HIS (Hollandsch Inlandse School), yaitu sekolah dasar dengan bahasa pengantar bahasa Belanda. Selain itu ada sekolah DAMAI (Sekolah Dasar Masyarakat Indonesia) dan Kulliyatul Mu'allimin El Islamiyah (KMI), sekolah Guru Agama Putra pada tahun 1940. KMI putra ini didirikan untuk memenuhi kebutuhan masyarakat akan guru-guru agama putra yang banyak didirikan oleh masyarakat di Sumatera Barat. Pada zaman Jepang lembaga pendidikan putri yang sudah didirikan Rahmah tersebut tidak dapat diteruskan. Hal ini karena pada zaman Jepang, semua sekolah harus serba budaya Jepang dan semua sekolah harus memakai kurikulum ala Jepang.

Dalam sistem pendidikannya, Rahmah menganut sistem pendididkan terpadu, yaitu; memadukan pendidikan yang diperoleh dari rumah tangga, pendidikan yang diterima di sekolah dan pendidikan yang diperoleh dari masyarakat di dalam pendidikan asrama. Dalam sistem terpadu ini, teori ilmu pengetahuan dan agama serta pengalaman yang dibawa oleh masing-masing murid dipraktekkan dan disempurnakan dalam pendidikan asrama di bawah asuhan guru-guru asrama.

Tantangan mendirikan sekolah pada masa penajajahan memang cukup sulit bagi Rahmah. Pemerintah kolonial selalu memperhatikan gerak-gerik Rahmah beserta lembaga pendidikan yang beliau dirikan. Beliau juga tidak mau bekerja sama dengan pemerintah kolonial. Hal ini ditunjukkannya ketika pemerintah mau memberikan bantuan subsidi pendidikan untuk sekolah yang Rahmah dirikan, namun beliau tolak. Hal ini karena akan menjadikannya bawahan pemerintah dan harus terikat dan tunduk pada pemerintah kolonial. Di dunia politik, meskipun tidak terjun secara langsung, Rahmah adalah seorang nasionalis sejati yang tidak bisa tawar-menawar. Beliau juga menolak ordonansi guru yang ingin diterapkan Belanda pada sekolah-sekolah swasta. Pemerintah Belanda sangat menyoroti dan mengawasi semua kegiatan di sekolah Rahmah, Diniyyah Putri. Pemerintah kolonial sangat mencurigai sekolah tersebut sebagai sarana untuk revolusi dan memperjuangkan kemerdekaan Indonesia ketika itu serta menjadi tameng untuk mengadakan perlawanan terhadap pemerintah.

Pada awalnya Diniyyah Putri muncul sebagai tantangan terhadap adat, dalam hal ini perempuan ingin melangkah melampaui urusan rumah tangga. Dengan menggapai peran-peran di luar rumah (domestik) yang dapat didukung oleh penafsiran kaum modernis terhadap Islam, oleh karena itu kaum perempuan memperluas pengetahuan, jaringan, dan kemampuannya untuk ikut serta dalam wacana muslim dan nasionalis yang lebih luas. Perempuan Minangkabau memiliki strategi alternatif, selain yang disuarakan oleh Diniyyah Putri menyangkut bagaimana menjadi seorang muslim tetapi juga menyangkut tradisi adat Minangkabau yang membuat perempuan juga memiliki posisi yang sama dengan laki-laki. Ini juga dituangkan oleh Rahmah dalam pemikirannya; "membangun masyarakat tanpa mengikutsertakan kaum perempuan adalah bagai seekor burung yang ingin terbang dengan satu sayap saja. Mendidik perempuan berarti mendidik seluruh manunsia."

\section{KESIMPULAN}

Perbedaan ideologi, budaya dan waktu antara Kartini dan Rahmah adalah beberapa hal yang sangat unik. Perjuangan dua tokoh ini tentu sangat berbeda, tetapi 
memiliki tujuan yang sama yaitu memperjuangkan hak perempuan terutama dalam pendidikan serta meningkatkan derajat kaum perempuan yang terikat oleh adat istiadat. Jawa yang kental dengan feodalismenya, Minangkabau dengan Matrilinealnya secara harfiah sangat berbeda. Namun di dalam prakteknya, perempuan Minangkabau juga diperlakukan hampir sama dengan perempuan Jawa yaitu tidak mendapatkan pendidikan dan terkurung oleh adat masing-masing. Yang paling disorot yaitu perempuan rela dijodohkan dan rela dimadu oleh laki-laki. Ini hal yang lumrah pada masa itu. Dalam kondisi inilah para tokoh perempuan hadir untuk memperjuangkan hak kaum perempuan yang direbut kebebasannya oleh adat masa itu.

Perempuan Minangkabau pada masa penjajahan, bisa dikatakan menikah di usia yang relatif muda. Rata-rata pada usia sebelum umur 20 tahun, perempuan sudah dinikahkan oleh mamak-mamaknya (paman). Ini terjadi karena kebiasaan adat pada zamannya yang mengharuskan perempuan harus cepat menikah. Ini terjadi karena beberapa alasan, pertama karena sistem matrilineal sekaligus matriarkat, di mana harta pusaka dijaga oleh anak perempuan, sehingga anak perempuan juga harus memiliki keturunan anak perempuan agar harta pusaka dapat dijaga dan diturunkan untuk anak cucu kelak. Kedua, perempuan Minangkabau adalah penghuni rumah dan kebesaran dari "rumah gadang" rumah tradisional Minangkabau, harus dilestarikan dengan keturunan dari perempuan Minang itu sendiri.

Penulisan terhadap ketokohan perempuan dalam sejarah Indonesia masih terlalu sedikit. Padahal di dalam sejarah tersebut masih banyak tokoh-tokoh perempuan yang belum diangkat ke publik. Hal ini agar sejarah dalam perjalanannya tidak bias antara laki-laki dan perempuan. Kartini sebagai tokoh perempuan yang bisa dibilang feminis, dan Rahmah dengan pendidikan islamnya memberikan nuansa yang berbeda. Hal ini memberikan warna dalam sejarah Indonesia. Banyak tokoh yang harus digoreskan lagi dalam tulisan dan karyakarya sejarah lainnya sehingga sejarah menjadi keilmuan yang adil akan gender dan tidak menjadi bias lagi.

\section{DAFTAR PUSTAKA}

Saydam, G. 2009. 55 Tokoh Asal Minangkabau Di Pentas Nasional. Bandung: ALFABETA.

Rosyadi, I. 2010. R. A. Kartini (Biografi Singkat 1879-1904). Yogyakarta: GARASI

Bandaro, L D dkk. 2004. Minangkabau yang Gelisah; Mencari Strategi Pewarisan Adat dan Budaya Minangkabau untuk Generasi Muda (Ed). Bandung: Lubuk Agung.

Kartini. 1963. Habis Gelap Terbitlah Terang. Jakarta: PN BALAI PUSTAKA.

Nuryanti, R. 2011. Perempuan Berselimut Konflik (Perempuan Minangkabau di Masa Dewan Banteng dan PRRI. Yogyakarta: Tiara Wacana.

Wierenga, S.E. 1999. Penghancuran Gerakan Perempuan di Indonesia. Jakarta: Garba Budaya.

Srinthi. 2006. Selamat Tinggal Kartini, Selamat Datang Ratu Kalinyamat. Media Perempuan Multikultural

Syafieh. Pemikiran Pendidikan Rahmah ElYunusiyyah, diposting tanggal 16 Februari 2013 